\title{
Giuseppe Arcimboldo’s Grilli: Humor and Magic in Genre Portraits*
}

\author{
Liana De Girolami Cheney \\ Universidad de Coruña, Spain
}

\begin{abstract}
This essay examines one aspect of Giuseppe Arcimboldo's portraiture: His genre depictions where he expands the art of illusionism or magic visualization into grilli (intellectual whims) and teste composte (composite heads). These images of reversible portraits of genre scenes, caricatural conceits, and visual puns are seen in The Cook or The Chef reversed as The Bowl of Meats of 1570 at the Nationalmuseum, Stockholm; The Vegetable Gardener reversed as The Bowl of Vegetables of 1590 at the Museo Civico "Ala Ponzone”, Cremona; and Il Frutaio, The Fruit Vendor reversed as The Basket of Fruits of 1591, at the French \& Company Gallery in New York. In his imagery, Arcimboldo focuses on the paradoxical meaning of objects, “what if?” adding a sense of ambiguity and mystery to his art. Is Arcimboldo teasing the viewer with a Mannerist flare, or is he composing or implying another type of intellectual conceit? Ultimately, Arcimboldo invents a new type of genre: the emblematic humorous portrait.
\end{abstract}

Keywords: composite heads, grilli, humor, delight, innuendo, symbolism, mannerism, Milan, School of Prague, art theory, grotesque

The Mannerist painter Giuseppe Arcimboldo (1527-1593) was born in Milan in 1527, the son of artist Biagio Arcimboldo and Chiara Parisi (Kaufmann, 1976; Zeri, 2001/1998; Kaufmann, 2010; Cheney, 2008/2013/2015; Baltrusaïtis, 1987; Ferino-Pagden, 2007; Ferino-Pagden, 2018; Geiger, 1954). ${ }^{1}$ He died on July 11, 1593, in his native city (see Figures 1, 2, and 3). Arcimboldo's sepulture rests in the Church of San Pietro della Vigna. In the Magistro della Sanità of Milan, the death certificate records that he died at the age of 66 of kidney stones and urinary tract occlusion “without suspicion of plague” (Morigia, 1595).

\footnotetext{
* Acknowledgement: A short version of this essay was presented in the session on Caricature at the International Conference of Art History of the Association of Art History at the University of East Anglia, Norwich, UK. I want thank Prof. Katarzyna Murawska-Muthesius, Department of History of Art, Birkbeck College, University of London, for her invaluable suggestions. Liana De Girolami Cheney, Ph.D., Visiting Researcher in Art History, SIEALE Universidad de Coruña, Galicia, Spain.

1 The Arcimboldo family is of noble origin from southern Germany. Some of them settled in Lombardy during the Middle Ages. Considerable variation is found in spelling of the name: Arcimboldi, Arisnbodle, Arcsimbaldo, Arzimbaldo, or Arczimboldo. The suffix "boldo" or "baldo" derives from medieval German. There is likewise variation in how Arcimboldo signed his first name: Giuseppe, Josephus, Joseph, or Josepho. See Benno Geiger (1954), the first complete monograph with copious documentation on the artist's life and career. For retrospective exhibitions with catalogues on Arcimboldo, in Venice at the Palazzo Grassi in 1987, see Baltrusaïtis, 1987; in Paris at the Musée du Luxemburg in 2007, see Ferino-Pagden, 2007; and recently in Rome at the Galleria Nazionale d'Arte Antica di Palazzo Barberini in 2018, curated again by Ferino-Pagden (2018).
} 


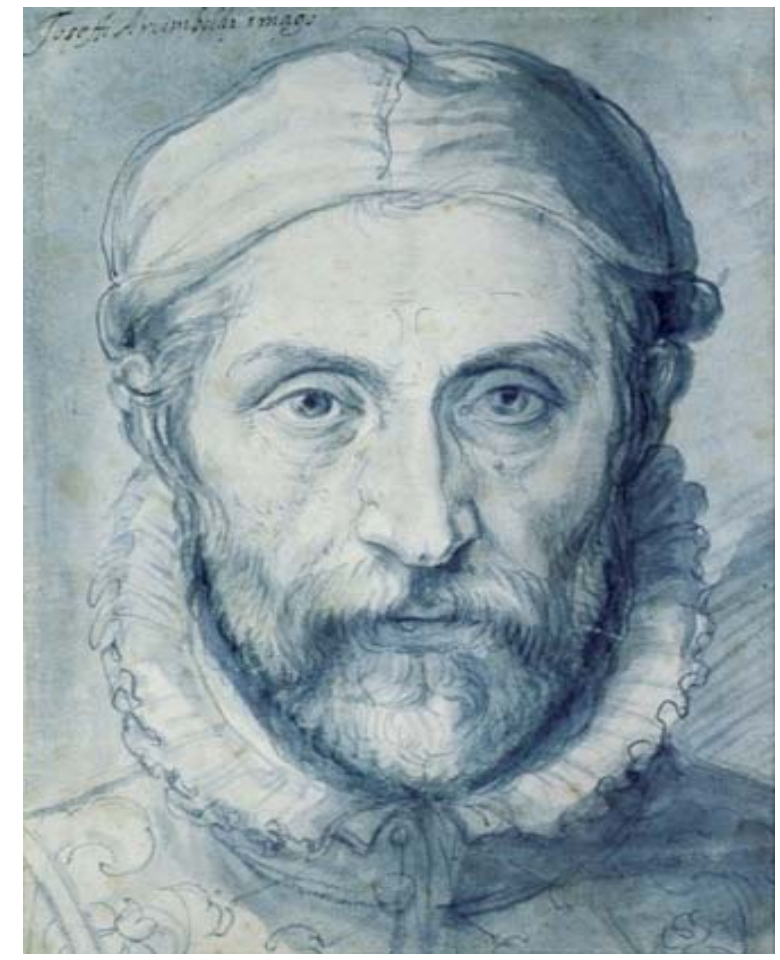

Figure 1. Giuseppe Arcimboldo, Self-Portrait, 1570. Drawing. National Gallery, Prague.

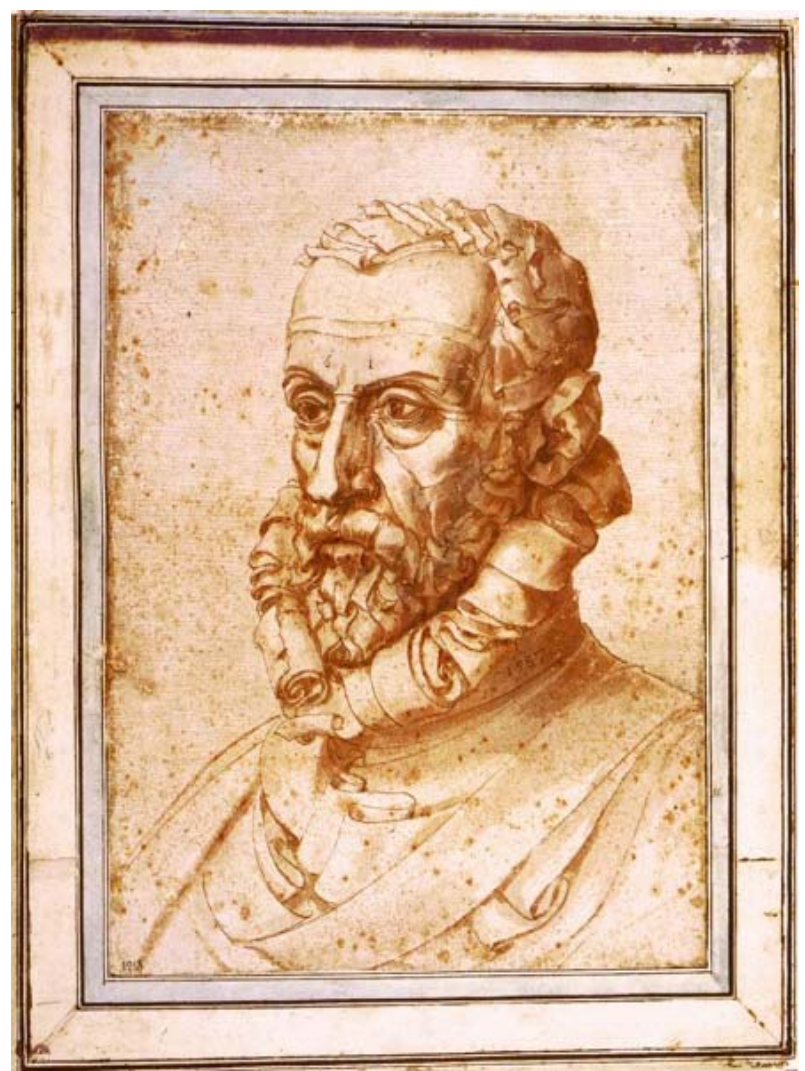

Figure 2. Giuseppe Arcimboldo, Self-Portrait, 1587. Drawing. Gabinetto Disegni e Stampe, Palazzo Rosso, Genoa (inv. D 1213). 


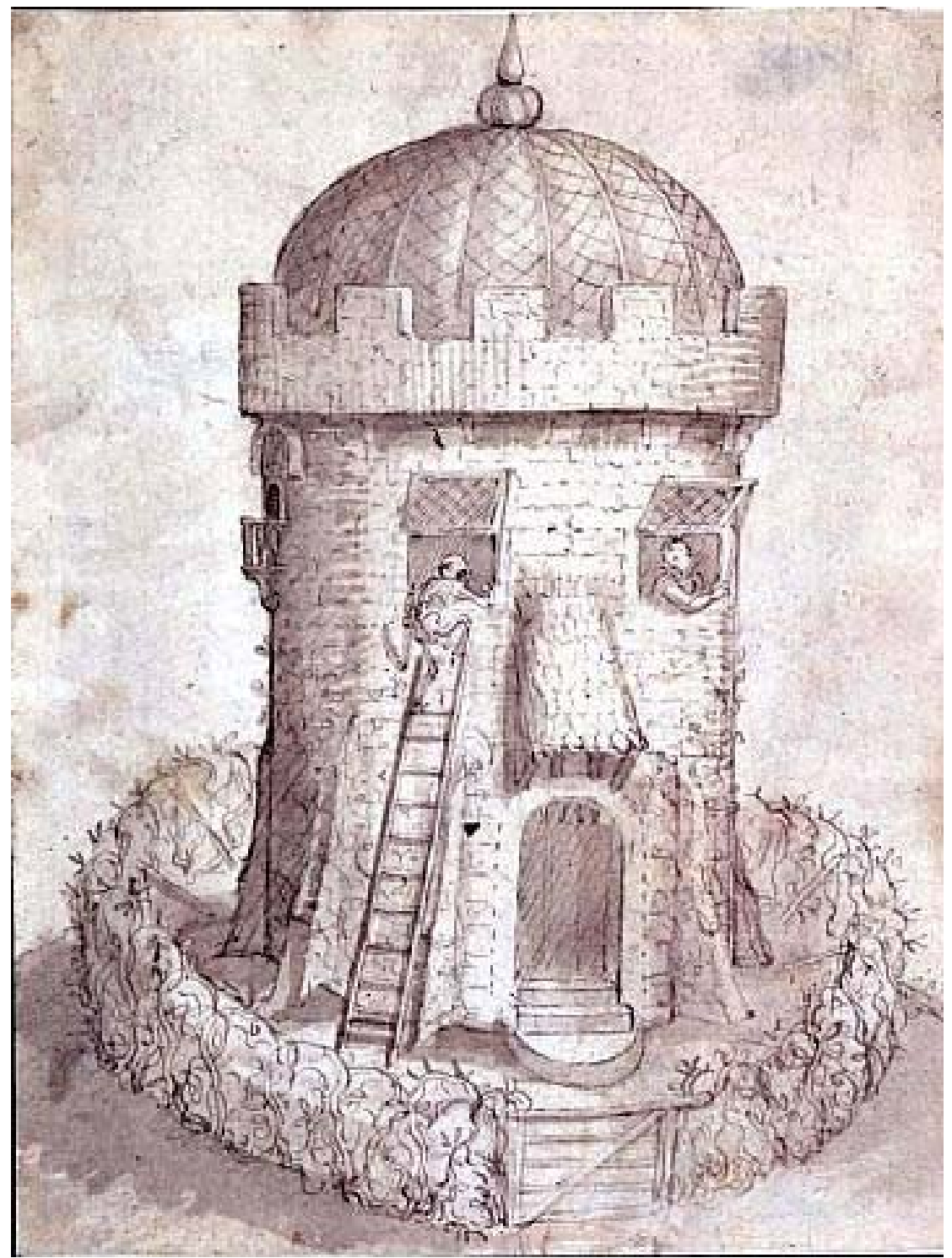

Figure 3. Giuseppe Arcimboldo, An Allegory of Death (Self-Portrait?), 1590s. Drawing. Sotheby’s London, July 10, 2002, Lot 103.

In Milan, Arcimboldo was trained in the arts by his father and the Lombardian school of artists, including Giuseppe Medea (active in Milan 1551-1559) and Bernardino Campi (1522-1591), a distinguished Cremona painter. Leonardo da Vinci's artistic and scientific spell is also felt in Arcimboldo's art. His father Biagio had the good fortune to befriend Bernardino Liuni, a pupil of Leonardo da Vinci, who, after Leonardo's death, acquired several of the master's notebooks and sketches. Biagio Arcimboldo surely studied them, and years later instructed his son Giuseppe on the Leonardesque artistic and scientific style. As a result of their friendship, Luini honored Biagio with a drawing portrait in profile (now at the British Museum in London) (Cheney, 2008/2013/2015; Kaufmann, 2010; Ferino-Pagden, 2007). ${ }^{2}$

The purpose of this study is to examine one aspect of Arcimboldo's portraiture, viz., his genre depictions, where he expanded the art of illusionism or magic visualization into grilli (intellectual whims) and teste

\footnotetext{
${ }^{2}$ For Bernardino Luini’s Portrait of Biago Arcimboldo, British Museum, London (inv. JCR 320).
} 
composte (composite heads). These images of reversible portraits of genre scenes, caricatural conceits, and visual puns are seen in The Cook or The Chef reversed as The Bowl of Meats of 1570 at the Nationalmuseum, Stockholm (see Figure 4); The Vegetable Gardener reversed as The Bowl of Vegetables of 1590 at the Museo Civico “Ala Ponzone," Cremona (see Figure 5); and Il Frutaio, The Fruit Vendor reversed as The Basket of Fruits of 1591, at the French \& Company Gallery in New York (see Figure 6). In his imagery, Arcimboldo focused on the paradoxical meaning of objects, "what if?" adding a sense of ambiguity and mystery to his art. Is Arcimboldo teasing the viewer with a Mannerist flare, or is he composing or implying another type of intellectual conceit? Arcimboldo invented a new type of genre: the emblematic humorous portrait.
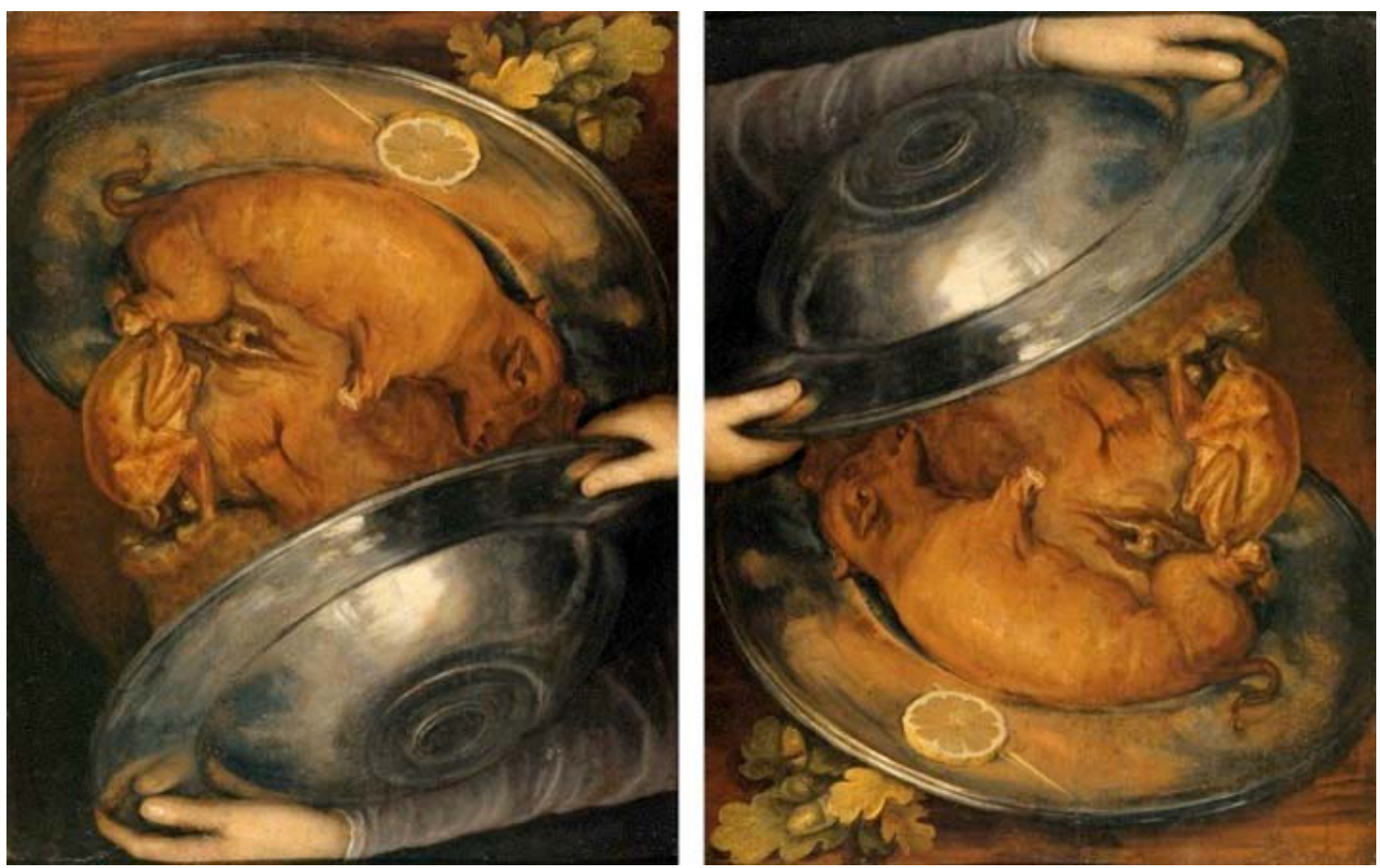

Figure 4. Giuseppe Arcimboldo, The Cook or The Bowl of Meats, 1570. Nationalmuseum, Stockholm. 

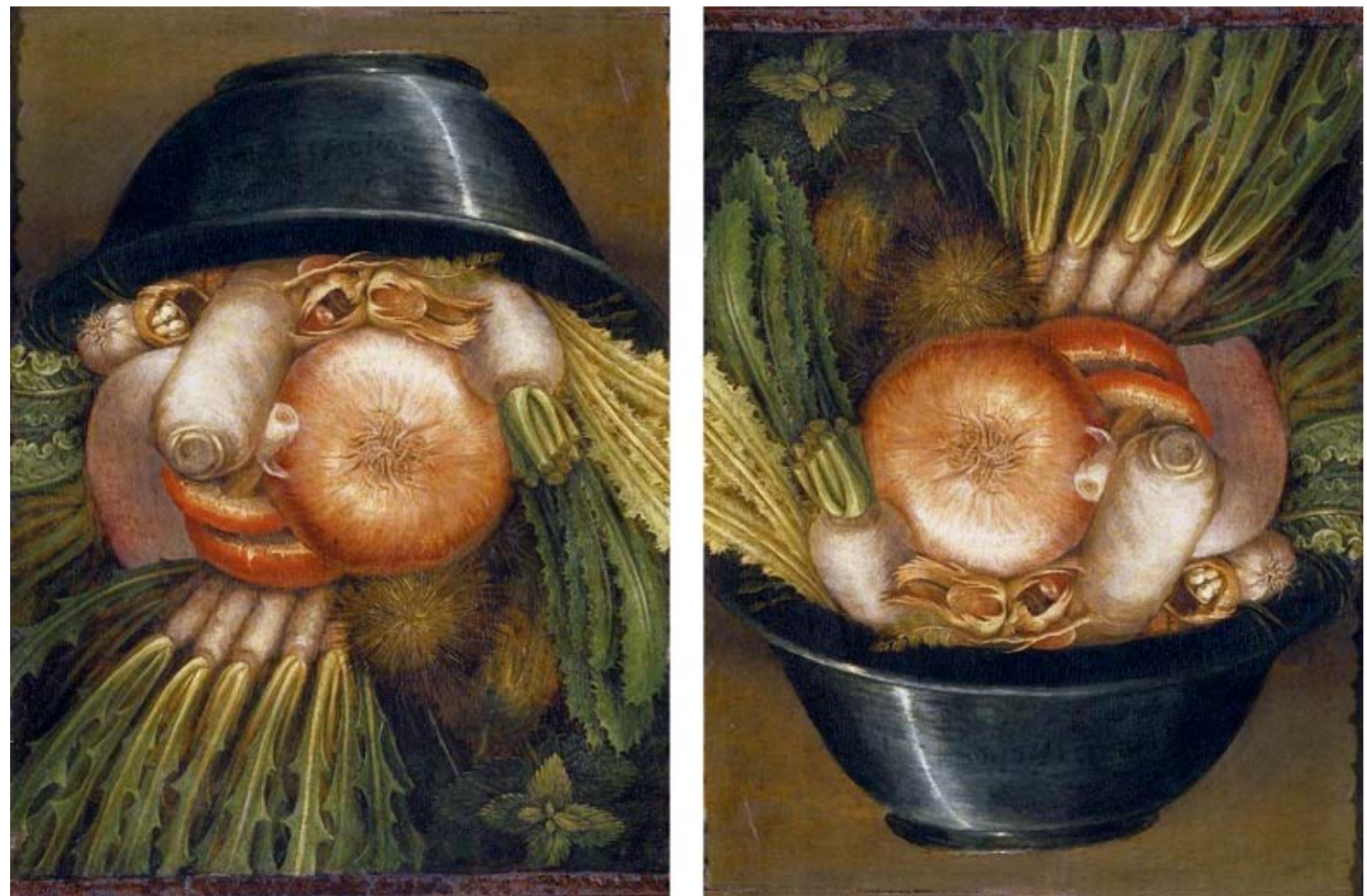

Figure 5. Giuseppe Arcimboldo, The Vegetable Gardener or The Bowl of Vegetables, 1590. Museo Civico, "Ala Ponzone”, Cremona.
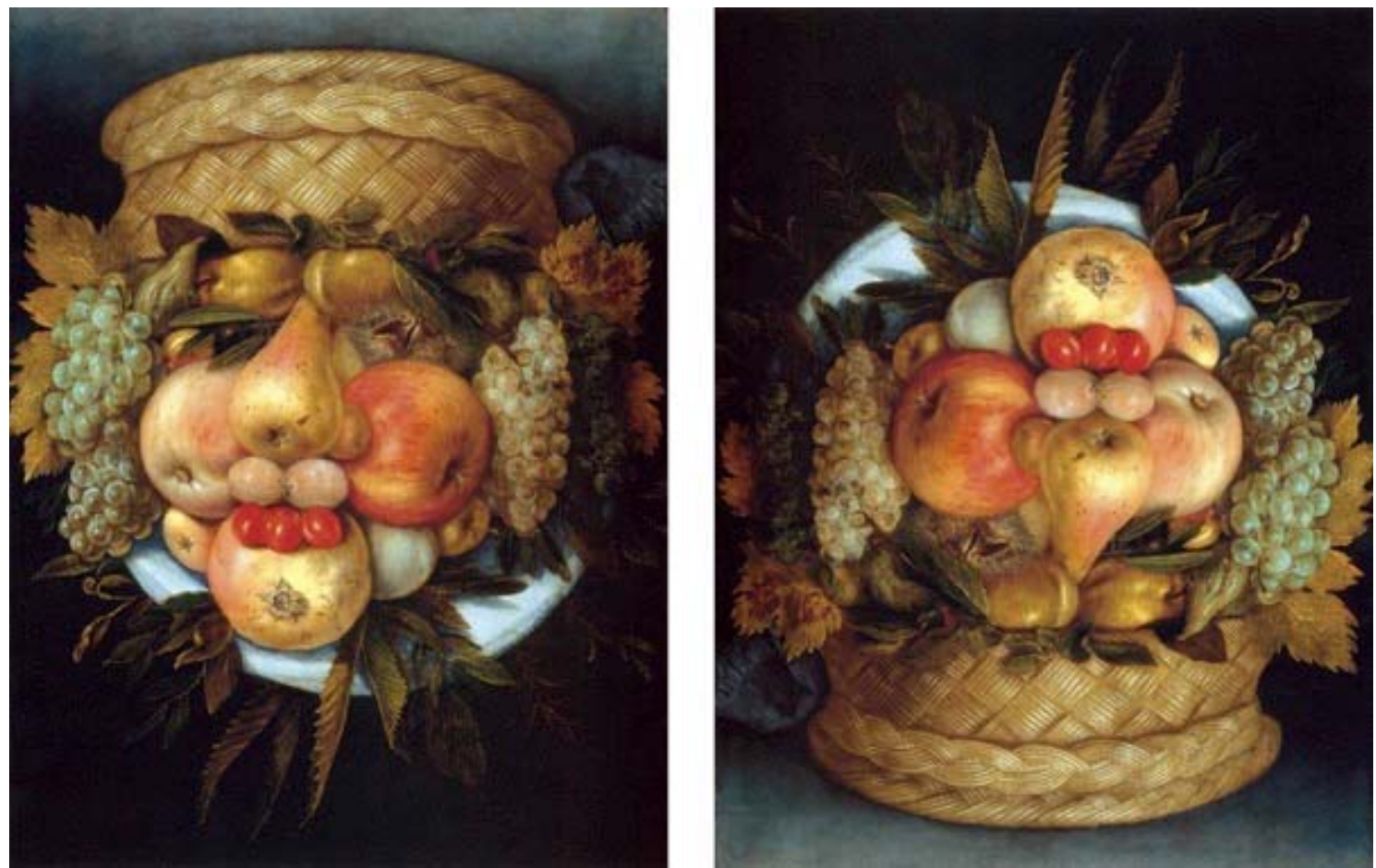

Figure 6. Giuseppe Arcimboldo, Il Frutaio or The Fruit Vendor or The Basket of Fruits, 1591. French \& Company Gallery, New York. 
Arcimboldo's emblematic portraits are depiction of grilli, intellectual conceits, recalling, and elaborating on the topsy-turvy world (il mondo alla rovesca) portrayed in the paintings of Hieronymus Bosch's Haywagon of 1510 at the Museo del Prado, Madrid (see Figure 7), and Peter Breughel the Elder's The Blind Leading the Blind of 1568 at the Museo di Capodimonte, Naples (see Figure 8). These artists' grilli were accompanied by didactic and moral messages conveyed through illusionistic depiction of the seven deadly sins, the senses, and vanitas. But Arcimboldo's portrait personifications as grilli are intellectual conceits or whims, demonstrating his virtuoso artistic talent and lacking a moral message but encoding an intellectual rebus. Thus the Milanese painter-poet, Arcimboldo, aggrandized himself as well as his patrons, the Hapsburg family, and their intellectual court in Prague (Kaufmann, 1988).

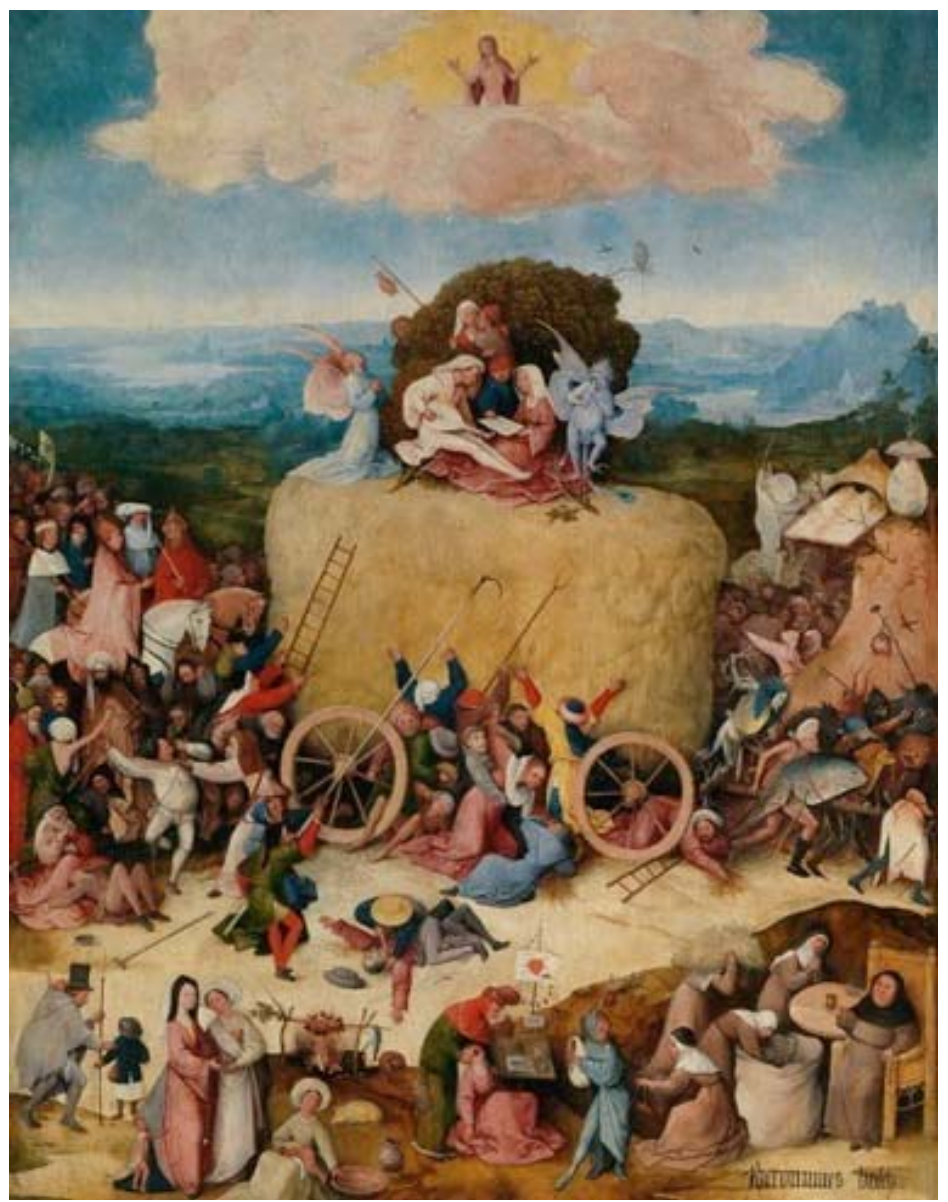

Figure 7. Hieronymous Bosch, Haywagon, 1515, central panel. Museo del Prado, Madrid. 


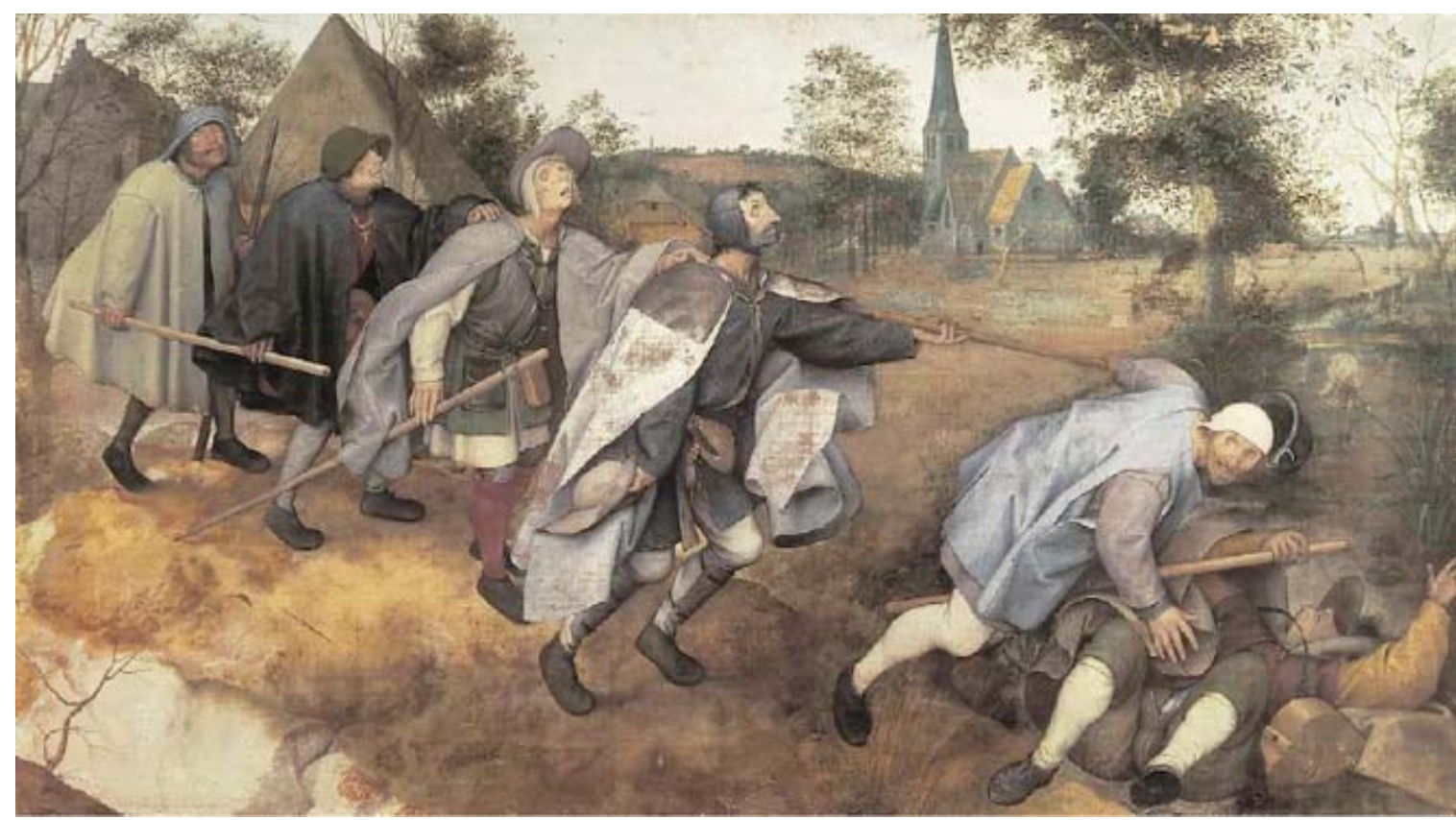

Figure 8. Pieter Bruegel the Elder, The Blind Leading the Blind, 1568. Museo di Capodimonte, Naples.

Scholars have put forth a variety of interpretations of the 16th-century Italian word grilli. For some scholars, grilli means jokes or puns, while for others, it means intellectual conceits. Since Antiquity with Pliny the Elder, there has been a quest to define and explain the meaning of artistic whimsicality or capriciousness (Rackham, 1952). ${ }^{3}$ In 16th-century, Italy grillo was defined as an idea "capricciosa, bizzarra, capriccio ghiribizzo", which refers to a whimsical or capricious idea, curious or fancy ideas (whim whams) (Vocabolario degli Accademici della Crusca, 1729). Or it was defined as a riddle, a "grillo è un indovinello di cui si conosce la soluzione”, meaning grillo is a riddle whose solution is known (Orlandi, 1704; Benno Geiger, 1954; Lanzi, 1796). Another Italian usage for grilli is "avere grilli per la testa", meaning to have shackles on one's mind.

Arcimboldo's contemporaries considered his work as fantastic or capricious. For example, the painter Giovanni Paolo Lomazzo in Idea del tempio della pittura referred to his imagery as inspired by "barroom pictures”; the art theoretician Gregorio Comanini in Il Figino commented on his pictures as scherzi (jokes); and the historian Paolo Morigia in Della nobilità di Milano called the paintings bizarrie (bizarre compositions) (Lomazzo, 1584; Comanini, 1591; Morigia, 1592). Similar views of Arcimboldo's work continued on into the 18th-century with P. A. Orlandi and Luigi Lanzi, and into the 20th-century with Benno Geiger (Orlandi, 1704, Benno Geiger, 1954; Lanzi, 1796).

Discourse among scholars focused on the variety of interpretations, usage, and meaning of the 16th-century Italian word grilli in connection to the meaning of a term used in the 18th-century, caricature. In contemporary writings, Thomas DaCosta Kaufmann has challenged this traditional view that Arcimboldo's imagery, in particular, the imagery of the Four Seasons and the Four Elements cycle, was strictly composed for personal jokes, oddities, or caricatures to make humor or to make fun of the Hapsburg Imperial Court (Kaufmann, 1976; Ferino-Pagden, 2007). The Holy Roman Emperors, Maximillian II and Rudolph II of the Hapsburg court, commissioned The Four Seasons or the Four Elements, and Arcimboldo repeated their themes

\footnotetext{
${ }^{3}$ See Rackham (1952), Vol. 9, Section 344 (Book 35, p. 114), for the use of the word grilli to describe a type of genre art by the ancient painter Antiphilus.
} 
several times in 1563, 1569, 1573, and 1575-1577 (Kaufmann, 1976, Cheney, 2008/2013/2015, Ferino-Pagden, 2007). ${ }^{4}$ The numerous versions of the Four Seasons cycle accompanied by the Four Elements cycle occupy a large part of his artistic endeavors during his residence at the imperial court. In conception, the cycle of the Four Seasons is connected to the Four Elements. ${ }^{5}$

The Four Seasons and The Four Elements are designed as bust portraits in profile, constructed as pendants to each other or facing each other. This symmetrical pairing creates a dialogue between them. Their interaction is also depicted by the expression of how the images look at or react to each other: surprise, laughter, amazement, or disappointment. The pairing is also connected with the personification of the ages of the individual: a child-like expression for air and spring contrasts with a youthful, smiling, and insecure appearance for summer and fire. The well-being of Earth and autumn manifests adulthood, whereas the struggling of old age is depicted by winter and water. Arcimboldo also introduces an aspect of gender in these cycles, alluding to humanity; e.g., summer is portrayed by a young woman, spring by a young male, autumn by a mature man, and winter by an aging man. The portraits are composed of four parts: a face in profile with an expression, a head with a crown, a large collar, and a torso with a spherical motif. These compositional parts allude to an imperial symbolism, e.g., images of a ruler, a crown, an honorific chain, and a scepter. Each season typically holds a natural element. For example, the seasons: Spring an iris or a flower, Summer an artichoke or a vegetable, Autumn a rose or a flower, and Winter a lemon or a fruit. And the elements: Air a bird, Fire a burning element, Earth a hunting animal, and Water a fish. In the cyclical formation of the four seasons and the experience of the four elements, the individual perceives them through the senses (the Aristotelian classification of taste, touch, smell, sight, and hearing). In the depiction of the Four Seasons and Four Elements, Arcimboldo is aware of the significance and the potency of the identification in recognizing the object and its properties through the senses. He reveals in these paintings the sensations of taste, touch, sight, smell, and sound.

Arcimboldo's creation of the Four Seasons and Four Elements is most ingenious, and the cycles were composed with the poetical assistance of Milanese humanist Giovanni Baptista Fonteo (Joannes Baptista Fonteius Primio) at the court. Kaufmann's discovery of a Viennese manuscript and Latin poems dedicated to Emperor Maximilian II by Fonteo explained the meaning of Arcimboldo's depiction of the Four Seasons and the Four Elements, as well as his other paintings (Kaufmann, 1976, Cheney, 2008/2013/2015, Ferino-Pagden, 2007). Fonteo defined grilli as grillus "a type of painting made up of instruments or other things pertaining to the image depicted, which provided the clavis interpretandi for the meaning of Arcimboldo's grilli" (Kaufmann, 1976, pp. 281-282; Cheney, 2008/2013/2015, p. 17). ${ }^{6}$ Hence for Kaufmann the meaning of the grilli are celebratory of the Hapsburg imperial court and its rulers. The personifications are grilli, intellectual conceits, to aggrandize the benevolent power of the Hapsburg emperor and reference to the harmonious nature

\footnotetext{
4 For some images of The Four Seasons and The Elements, see http://www.sothebys.com/en/auctions/ecatalogue/2013/old-master-british-paintings-evening-l13033/lot.32.html (accessed January 2, 2019); https://i.pinimg.com/originals/e6/ff/fc/e6fffc284cb0ad0a369c3f3be91337f8.png (accessed January 2, 2019); https://commons.wikimedia.org/wiki/File:Giuseppe_Arcimboldo_-_Pairs_of_Allegories_-_WGA00831.jpg (accessed January 2, 2019); and https://en.wikipedia.org/wiki/The_Four_Elements_(Arcimboldo) (accessed January 2, 2019).

${ }_{5}$ Not all the paintings for these cycles have survived. The dispersion of the individual paintings from the cycle or the whole cycle complicates our understanding of the meritorious nature of Arcimboldo's art. These cycles were praised by late 16th-century artists, theorists, and writers, such as Giovanni Paolo Lomazzo in Idea del tempio della pittura (Milan 1590), Gregorio Comanini in Il Figino, ovvero del fine della pittura (Mantua 1591), and Paolo Morigia in Historia dell'antichità di Milano (Venice 1592).

${ }^{6}$ See also G. B. Fonteo's manuscripts, Codeci 10152, 10206, and 10466 of the Österreichische Nationalbibliothek in Vienna, as cited in Kaufmann (1976) and Cheney (2008/2013/2015).
} 
of his reign (Kaufmann, 1976). Thus, Arcimboldo and Fonteo established a new category of genre for imaginary and composed portraits.

In addition, in the 16th-century, the Italian term teste composte was defined as "i ritrati e busti allegorici basati sull'illusione della figura, ottenuta attraverso composizioni di fiori, frutta, verdure e animali”, meaning "composite heads alluding to allegorical bust and portraits based on an imaginary figure, which is created from arrangements containing flowers, fruits, vegetables and animals” (Benno Geiger, 1954, p. 77).

Paradoxically, although perplexed by Arcimboldo's art, his Milanese contemporaries, such as Giovanni Paolo Lomazzo in Idea del tempio della pittura (Milan 1590), Gregorio Comanini in Il Figino, ovvero del fine della pittura (Mantua 1591), Paolo Morigia in Della nobilità di Milano (Milan 1595), and Historia dell'antichità di Milano (Venice 1592)—nonetheless praised Arcimboldo's paintings highly. In the Trattato dell'arte della pittura of 1584, Giovanni Paolo Lomazzo described Arcimboldo's paintings in terms of artificio (artifice, a cunning device) where it is still possible to make an image that, when turned upside down from above, appears to have other figures in front of our eyes, related to but very unsettled from the first already seen, and many other similar bizarre images can be made (Lomazzo, 1584) ${ }^{7}$

In Della nobilità di Milano, Paolo Morigia (1525-1604) recorded the history of Arcimboldo's family (Morigia, 1595; Kriegeskorte, 1993). ${ }^{8}$ To substantiate his claim, Morigia reported that his notations "derived directly from Mr. Giuseppe Arcimboldo, a trustworthy gentleman with an impeccable lifestyle, "Pittore raro, $e$ in molte altre virtù, studioso, e eccellente; e dopo l'haver dato saggio di lui, e del suo valore, così nella pittura come in diverse bizarrie, non solo nella patria, ma anco fuori, acquistossi gran lode" (Unique painter and with many other talents, studious, and excellent; and after commenting on him and on his merit, similarly was in the art of painting with numerous capriciousness, he achieved great praise not only in his country, but also outside) (Morigia, 1592, pp. 566-567).

Furthermore, in Historia dell'antichità di Milano of 1592/1595, Morigia provided an account of the significance of the Arcimboldo family's patronage at the imperial court of Ferdinand I and his successors, Maximilian II and Rudolph II, when Arcimboldo in 1562 settled in Prague as a portrait painter and copyist for the Hapsburg family, replacing the elderly Jacob Seisenegger. “Arcimboldo,” Morigia noted: “...was liked and treated well, and received with great kindness, and the Emperor gave him a good salary worthy of his merits and also showed his affection in many other ways” (Morigia, 1592, pp. 566-567). ${ }^{9}$

Between 1550 and 1558, Arcimboldo worked under religious patronage: for the Duomo of Milan, he composed stained-glass windows on the Stories of St. Catherine of Alexandria; and for the Cathedral of Como he composed tapestries on the Life of the Virgin Mary. When from 1560 to 1580 he worked under the patronage of the secular Hapsburg court in Vienna and Prague, Arcimboldo was quick to create a new style that, although Mannerist in conception was devoid of religious overtones. The aim of the Hapsburg emperors was to create a glorious empire, to surround the court with the most distinguished humanists, scientists, and dignitaries

\footnotetext{
${ }^{7}$ Lomazzo (1584) wrote: “Arcimboldo, ci dà una descrizione precisa di questo artificio: 'ancora si possono fare medesimamente le figure perfette da vedere, che poi rivoltato quelle di sotto di sopra ci appaiono avanti agli occhi altre figure molto sconformi dalle prime già vedute e molte altre simili bizzarrie si possono fare'.”

8 Arcimboldo's personal life is obscure. It is uncertain whether he married Ottilie Strummer, who was of German origin. Their natural son Benedetto Arcimboldo was born on July 14, 1575, in Prague, and Emperor Maximilian II signed a certificate legitimizing the birth.

9 Satisfied with Arcimboldo's emblematic accomplishments for his insignia in 1551, Ferdinand I of Bohemia frequently invited him to accept an artistic position at the imperial court in Prague.
} 
of the time, such as Johannes Sambucus (1531-1584), a Hungarian humanist, scientist, historian, and collector of art who became court historiographer to the Habsburg emperors Ferdinand I, Maximilian II, and Rudolf II. In addition to his emblem text, in 1572, Arcimboldo designed triumphal arches for Maximilian II.

At the Hapsburg court Arcimboldo's artistic activities paralleled those of Leonardo da Vinci for the Duke of Milan and Giorgio Vasari's impresario ability for the Duke of Florence. He befriended and worked with the Milanese scholar Giovanni Battista Fonteo [Fontana] (1546-1580), who was well-known for his erudition in Latin history and his treatise on laughter, De Risu or De Risa, published in Latin in 1570 (Savio, 1905, Kaufmann, 2010). Fonteo's panegyric poetic style, containing Renaissance Neo-Latin literature and Neoplatonic philosophy, complemented Arcimboldo's complex imagery and Mannerist conceits. Both artists enjoyed designing and composing costumes, ornaments, and decorations for the imperial celebrations. Both the poet and the artist aimed to reveal universally the glorious power of the Hapsburg imperial family. To aggrandize their patron, the emperor, was to indirectly reveal their bravura and virtuosity as artists. Thus, both poet and artist sought resources from the ancient past as well as recent events for the creation of their mythical utopia.

Fonteo, as a humanist, was influenced by 16th-century classical tradition. He too consulted artists of this period, books of emblems, and mythological manuals as a source for visual and literary conceits (Praz, 1941/1947/1964; Russell, 1981). ${ }^{10}$ These manuals had a moral overtone and contained verbal and visual representations of virtues, vices, passions, and temperaments, revealing as well a Neoplatonic philosophy (Cheney, 2008/2013/2015). The most important manuals then available were Andrea Alciato's Emblematum Libellus, first published in Augsburg 1531; Vincenzo Cartari's Imagini delli dei degl' antichi (Venice 1556); Natale Conti’s Mythologiae (Venice 1551/1581); Lilio Gregorio Giraldi’s De Deis Gentium (Basel 1548); Francesco Colonna’s Hypnerotomachia Poliphili (Venice 1499); Horapollo’s Hieroglyphica (Venice 1505); Pierio Valeriano's Hieroglyphica (Basel 1556); Paolo Giovio's Dialogo dell'Imprese Militari et Amorose (Venice 1556); Johannes Sambucus, Emblemata (Antwerp 1564), who resided in the Hapsburg imperial court; (Praz, 1941/1947/1964; Seznec, 1953) as well as Desiderius Erasmus's Adagia (Adages) or Thousand Proverbs (Paris 1508). These texts were compilations of "antique mythology, Egyptian pictorial writing arbitrarily interpreted, Biblical motives, and medieval Christian allegory with all sorts of recondite meanings being assigned to human expressions and actions, to the animals, plants, prescribed colors, and all objects natural and artificial which were their symbolic attributes” (Ripa, 1603, Introduction). These texts included ancient and medieval mythographies, hieroglyphs, and numismatic sources. The texts served as manuals and recipe books for 16th-century humanists and artists-a kind of figurative encyclopedia or "dictionary-album for easy consultation when time was lacking to read text and reference in their entirety” (Ripa, 1603, p. 260; Praz, 1941/1947/1964, pp. 289-296). Since these manuals are well known to 16th-century artists and literati, they freely borrowed or copied information directly from them without acknowledging the original source.

Furthermore, in the 16th-century, the study of natural science was viewed as part of material culture, resulting in botanical gardens, botanical books, and curiosity cabinets or wunderkamer (kustkamer) (chamber of wonders) (Impey \& MacGregor, 2018; Mauriès, 2011). These kunstkamers or museums contained collections

\footnotetext{
${ }^{10}$ Russell explained the importance of Alciato's book in Cinquecento art and literature: "It served as a manual to train readers in a particular approach to artistic artifacts. It taught them to participate actively in the moralizing of visual art, and it showed them how to fragment texts-mainly poetic or dramatic texts; it would appear-into short passages that they could summarize into titular paroemia".
} 
of natural science and precious and rare objects found in nature and discovered in the New World (Maresca, 2012). Artists, such as Arcimboldo, imitating nature, composed and elaborated on new types of genre — still-lifes or portrait paintings — by incorporating flowers, fruits, animals, gems, and other natural forms in their art.

Arcimboldo infused his reversible genre portraits with a combination of classical and Christian motifs, following the illusionism of the 16th-century but adding a sense of humor, delight, and intrigue: a rebus to be decoded. Arcimboldo assimilated the all'antica motifs in the treatment of the figures, festoon decorations, and grotesques (grotteschi) of the Roman school of fresco paintings for the papal apartments and the Logge in the Vatican (Harpham, 1976; Kayser, 1981; Chastel, 2010, Zamperini, 2008; Acciarino, 2018). But his familiarity with this type of fanciful ornamentation is actually not only an assimilation of just the ancient Roman and Renaissance artistic influences but also of literary and visual tradition in northern Italy shown in the decorations for Francesco Colonna's Hypnerotomachia Poliphili (Venice 1499) (Calvesi, 1987) ${ }^{11}$ and most of all, in the pictorial decorations of Leonardo da Vinci in the Sala delle Asse (1495-1498) at Castello Sforzesco in Milan, as well as his studies of grotesque heads of the 1490s (drawings at the Royal Collection at Windsor Castle in London, and the Accademia in Venice) (Kwakkelstein, 1994; Clayton, 2002). ${ }^{12}$

In the imperial Hapsburg court, undoubtedly, Arcimboldo and Fonteo exchanged and shared ideas on how to glorify the court by employing paintings, pageantry, and poetry. With Fonteo's assistance Arcimboldo continued to investigate the world of imagination as well as the natural world. His ingenious mind composed images derived from the natural world and inspired by the literary and visual realm. However, Arcimboldo sometimes defied the universal laws of nature (the seasons, the elements, and the humors) in order to invent those laws in art (originality, imagination, idealization, and beautification).

As a Mannerist painter of the 16th-century, Arcimboldo was surrounded by global crises with the Church-conflicts between the Reformation and Counter-Reformation in the Christian world-and with governments-hostility from the European states against the Hapsburgs and tension between the Hapsburgs and the Ottoman Empire. Arcimboldo escaped by using his genius to create a world of "art for its own sake", where all the elements of nature coexist in peace as in the cosmos: in air, water, fire, and earth; where the four seasons provide the richness of life, where even in the winter life is resting but not deceased or destroyed; where the senses-hearing, sight, smell, touch, and taste-are physically and metaphysically in harmony. Arcimboldo invented an artistic utopia, a kaleidoscopic realm of colors and forms where only the beauty of the imagination reigns.

In comparing his early self-portraits, one notices Arcimboldo's playful discovery in composing visual ambiguity, a rebus to be decoded by the viewer, thus indicating the beginning of his expansion of the art of illusionism or grilli to imagery of reversible portrait of genre scenes, teste composte. His Study for a Self-Portrait of 1575 at the Národni Galerie (inv. K5338) in Prague (see Figure 1) (Zeri, 1998/2001; Cheney, 2008/2013/2015; Ferino-Pagden, 2007), for example, reflected Morigia’s character analysis of a courtier, a cultured and refined man, a Renaissance artist-prince or artist-philosopher as recalled in the books of

\footnotetext{
${ }^{11}$ See Calvesi (1987), discussing the influences of religious and secular works of Andrea Mantegna (1431-1506) such as the Zeno Altarpiece in Verona and the Camera degli Sposi in Mantua, as well as the numerous altarpieces of the Venetian painter Carlo Crivelli (ca. 1430-ca. 1495).

${ }^{12}$ Leonardo composed numerous bizarre heads as seen in his drawings, e.g., Libretto d'appunti. Codice Tivulziano n. $2162: 2$. Archivio Storico Civico, Biblioteca Trivulziana, Milan.
} 
Baldassare Castiglione's The Courtier (Venice 1528) and Giovanni della Casa's Galateo (Venice 1558). The grisaille drawing depicts a frontal portrait of the artist wearing a painter's cap and the traditional high-laced ruff. His jacket is simply decorated with flowery designs. His oval-shaped face-with trimmed beard, intense gaze, aquiline nose, and thin lips_-reveals his gentle nature. The partially open mouth with the focused gaze creates a powerful connection with, and a pleasant visual dialogue between, the sitter, Arcimboldo, and the viewer. Arcimboldo's personality and cultured manners are appropriate qualities for the imperial court. ${ }^{13}$

A different rendering is found in a second Self-Portrait in the Gabinetto Disegni e Stampe, Palazzo Rosso in Genoa (inv. D 1213), composed in pencil, pen, ink, and wash on paper and signed on the collar "1587" (see Figure 2) (Cheney, 2008/2013/2015; Ferino-Pagden, 2007). Arcimboldo portrayed himself as a learned man, thus contrasting with his earlier study where he depicted himself as an artist. In this drawing, he created an image of a sophisticated humanist dressed, in the fashion of the time, with elegant attire and a high-laced collar framing his face that sports a well-groomed beard. Although Arcimboldo shows what appears to be a natural rendition of the self, careful scrutiny reveals that he designed a type of composite head. He selected as a motif a rolled-up scroll, a parchment of paper, used for painting or writing, forming layers of rolled-up shapes as well as flat fragments stacked up. He started composing his bust frame by drawing a large ribbon with numerous folds that continuously encircles his shoulder. One edge of the ribbon connects with a smaller rolled-up ribbon that forms the high-laced ruff as ruffles around his neck. This decoration frames his face. His beard, lips, and moustache are composed of smaller scrolls, while the facial features of nose, cheeks, eyes, and forehead are designed of flat parchments. These fragmented parchments contrast to form a mask or a skeletal skull. The nose is rectangular and fragmented. Repetitious curved lines compose the eyes. The eyebrows are designed with superimposed layers of parchment. On the large forehead a large ribbon separates its surface. The scrolls from the beard connect with a large scroll that forms the ear and ear lobe and unites with the scrolls that form the hair. Curiously, the hair is designed with flat layers of parchment imitating laurel leaves, an ancient motif for crowing learned men, poets, or royal figures. In this Self-Portrait, Arcimboldo has honored himself as a painter and poet through the artistic motif of drawing and writing in the forms of parchment and scrolls. Arcimboldo is also visually alluding to Horace's classical motto ut pictura poesis (as is painting, so is poetry) (Cheney, 2017), as well as Comanini's commentary in Il Figino about these similitudes:

I know that the good painter needs to be as well read as the good poet, because his knowledge enables him to become another Proteus, transforming himself into diverse forms and dressing in the costumes of others, as is appropriate for a good imitator. (Doyle-Anderson and Maiorino, 2001, p. 27)

Another possible later portrait, metaphorical in composition and not natural as the previous works, is a design of An Allegory of Death of 1590s in the collection of Works on Paper at the Jean-Luc Baroni Ltd. Gallery in London (see Figure 3). The personification of death here is composed in the following manner. An enclosed garden, a hortus conclusus, contains a face in the shape of a medieval tower. The round hortus conclusus is formed with the ruffled collar of a courtly personage. The open mouth and tongue form a door with steps, the eyes are windows, and the head or crown is designed as a castle with a crenellated wall. A man climbing a ladder enters the tower's left window, while another man is seen closing the shutter of a right

\footnotetext{
${ }^{13}$ For another Self-Portrait of 1570, oil on panel, see Kaufmann, The School of Prague, p. 167, Fig. 2.10. The portrait is described in an inventory of the Prague collection as "a long man in a long black beard". Unfortunately, its whereabouts is unknown.
} 
window. Perhaps this allusion to death refers not only to Arcimboldo's personal illness but also to his departure from the Hapsburg's royal court and his return to Milan. ${ }^{14}$

Arcimboldo intertwined a metaphorical allusion of an image with the playfulness of game in the teste composte or teste reversibile, as portrayed in The Cook or The Chef, reversed as The Bowl of Meats; The Vegetable Gardener, reversed as The Bowl of Vegetables (Baltrusaïtis, 1987a; 1987b); and the Basket of Fruits, reversed as Il Frutaio, The Fruit Vendor. He played between the viewer's visual and tactile experience, between the reality of nature and the transformation of nature into an artistic form. What is real becomes an appearance and what is an appearance is an unreality. Perhaps this was designed to arouse laughter from the viewer, a technique that he learned from his association with Fonteo's poetry; or perhaps it was designed to raise the viewer to a higher level of intellectual experience, thus seeking a higher quest and meaning through the power of imagination. Ingeniously, Arcimboldo fused the physical realm of nature and the natural forms with the cosmological implications of the cycles of life, the seasons, and the elements, thus creating a utopia for the senses, that is, a visual feast to be aesthetically perceived by all viewers but only possible to be decoded by the intellect of the intelligentsia or humanists at the court.

Arcimboldo's The Bowl of Meats of 1570 at Nationalmuseum in Stockholm (see Figure 4) is a variant of an earlier painting depicting the Element of Earth of 1566 in a Private Collection in Vienna, where all hunting animals form a testa composta (Kaufmann, 1988). In The Bowl of Meats, Arcimboldo painted a silver plate with recently roasted, succulent meats: fowl, lamb, and pork. Reflections on the rim of the plate suggest the depiction of another portrait. Not by accident, he amusingly has placed a lemon slice on the rim. Two hands lift a silver lid covering the silver plate with meats. This image may allude specifically to the personifications of the senses. For example, the cooked meats may allude to the sense of taste; the lemon slice assists in reinforcing the sense of smell; and the glittery reflections of the metal plate evoke the sense of sight. When the painting is reversed, a different image is seen: The Cook depicts an ugly portrait of a man. His face is composed of various types of cooked meats: chicken, rabbit, and pork. A silver plate serves as a hat, whose reflections of cooked meats in the plate's rim accentuate the cook's role. A slice of lemon and an acorn plant form a plume, an allusion to the image of a fool at carnivals (Mardi Gras) or "Feast of Fools". This celebratory event mocks morality, rules, and codes for the sake of violence and rituals associated with sexual behavior and physical indulges. It is the triumph of the pleasure of the flesh, including eating. Perhaps, in a subtle manner, Arcimboldo was creating an allusion to one of the seven deadly sins, gluttony (the sin of gula). Arcimboldo's accuracy in the depiction of the animal forms is remarkable, in particular, the vegetation with the acorn plant, which recalls his Milanese artistic tradition as compared with Leonardo's drawing of an acorn plant (compare Figures 9 and 4$).^{15}$

\footnotetext{
${ }^{14}$ Another possible meaning for the drawing is an allusion to the death of a royal family member, in view that, in the drawing, the head is crowned, a symbol of sovereignty. See Maximilian II and his Family of 1563, at the Kunsthistorisches Museum in Innsbruck, in Zeri, Arcimboldo, p. 16. An ill Arcimboldo is also depicted with a lifeless expression in a painting recently attributed to Arcimboldo as a Self Portrait as The Four Seasons of 1593, in a private collection in Milan.

15

For the

image,

see

https://www.gettyimages.com/detail/news-photo/drawing-of-dyers-greenwood-and-oak-leaves-by-leonardo-da-news-photo/53955 7276 (accessed April 24, 2018).
} 


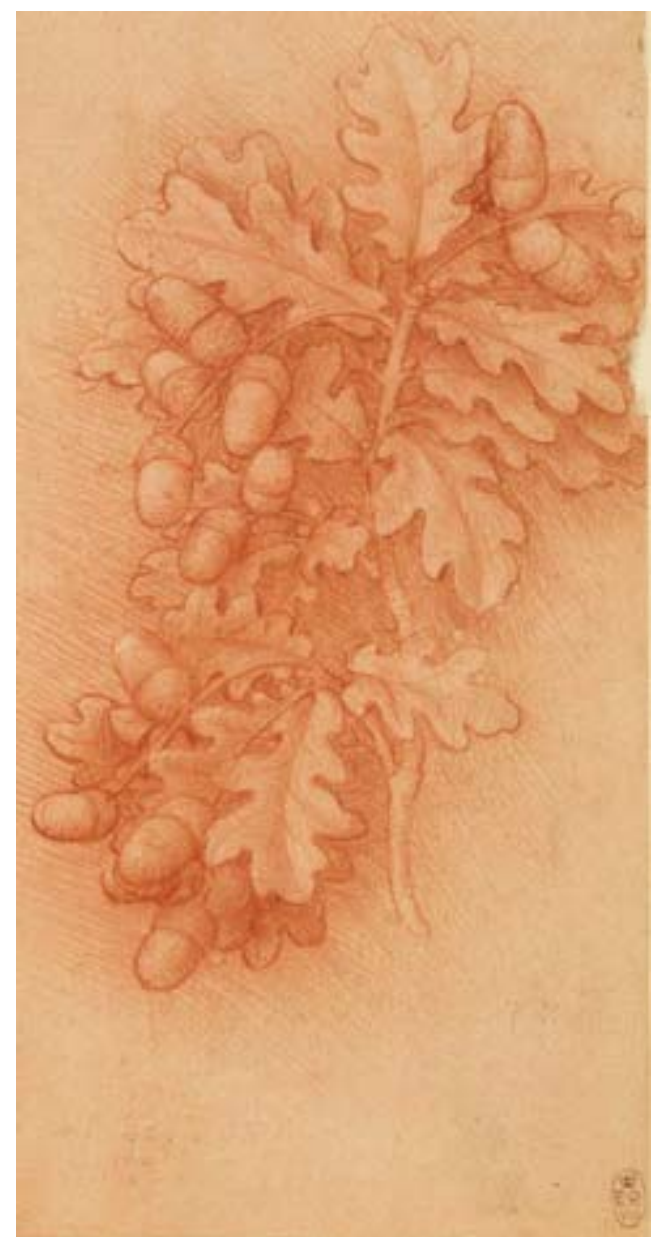

Figure 9. Leonardo da Vinici, Study of Oak Leaves with Cluster of Acorn, 1506-08, det. Drawing. Royal Library, Royal Castle Windsor (inv. RL12.422r).

Arcimboldo's composition also referred to Lomazzo's Self Portrait of 1568, at the Pinacoteca di Brera in Milan (see Figure 10) (Ferino-Pagden, 2007). Lomazzo composed a Mannerist portrait. The subject wears a Milanese straw hat (Castagno, 1994), ${ }^{16}$ worn by peasants, which contains an olive branch, grape leaves, and ivy. A large gold medal embossed with the image of a water pitcher with flowers is prominently pinned on his hat, in a diagonal direction to his eye, which has a humorous, sinister gaze. The texture of his trimmed beard contrasts with the bizarre hat while paralleling his soft hairy tunic. His right hand rests on a book or a drawing folder while holding a pincher or compass drawing tool. A lance resting on his shoulder is decorated with winding ivy on the pole in contrast to the pointed metal end. The lance, a perishable instrument of war, is controlled by ivy, an evergreen plant symbolizing endurance and renewal (Chevalier \& Gheerbrant, 1994). In this context, with the connection of water pitcher or wine holder, the ivy as vine is associated with Dionysus's rituals (Chevalier \& Gheerbrant, 1994). In his portrait, Lomazzo wears a golden ring on the index finger of his

\footnotetext{
16 The straw hat was worn by sixteenth-century Italian peasant women in the lands around Venice, as noted by Cesare Vecellio (1530-1601), an Italian engraver. In 1590, he wrote De gli Habiti Antichi e moderni di Diversi Parti di Mondo, published in Venice, with woodcuts. These designs were for the actors of the Commedia del Arte or Commedia all'mprovisto, a form of staged performance with masked types developed during the Mannerist period in the northern part of Italy. In this improvised performance, actors wore various masks and props (robbe). The renowned troupe of the Gelosi formed their own academy and performed in Rome and Venice.
} 
right hand, symbol of his wisdom as well knowledge of his art, since he is holding in the same hand the drawing device, the tool of his artistic trade (Chevalier \& Gheerbrant, 1994). In his article on "Giovanni Paolo Lomazzo" (Lynch, 1964; 1966), Justin Lynch discussed the symbolism of the portrait as well as the inscriptions at the bottom of the portrait. Lomazzo depicted himself as a Bacchus (Dionysus) with the corresponding attributes, vines, and foliage, dressed as the Abbot of the Accademia della Val di Blenio. This was an academy composed of a group of artists, jewelry makers, artisans, musicians, and actors who gathered together to be inspired by a mysterious Dionysian furor, a creative and poetic inspiration (Berra, 1998). At the bottom of the portrait, the bizarre inscription, written in the obscure Camasco language of the Canton Ticino, alludes to Lomazzo's acquired name for membership at the academy, zavargna.nabas.vallis.bregni.et.ipl.pitr 15 [...] (compà Zavargna). The "capelasc di paglia" (straw hat) refers to the humble hat wore by the facchini (peasants). The medal with the image of the water pitcher with flowers, the galeone, is the insignia of the Academy, symbolizing the idea of drunkenness in order to achieve Bacchic powers (furor poeticus). The pincher is a thief allusion from the Italian pizzico, used as a poetical reference to concepts of imitation in words and images, as well as alluding to Lomazzo artistic and poetical talents. The book he holds is his own poetical creation of Rabisch, which signifies grotesques (Tramelli, 2007; Isella, 1993).

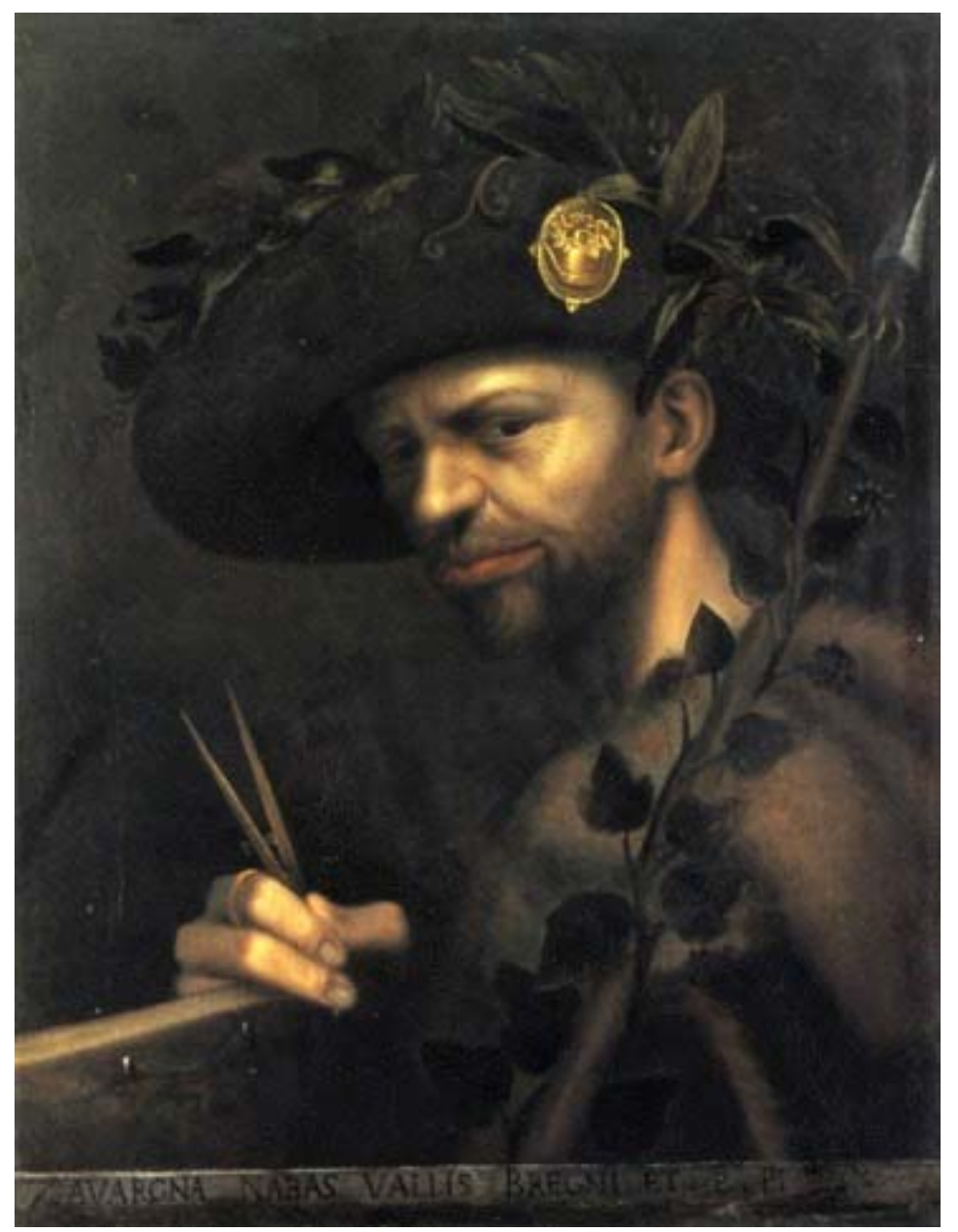

Figure 10. Giovanni Paolo Lomazzo, Self-Portrait, 1568. Pinacoteca di Brera, Milan. 
Arcimboldo inventively appropriated some symbols from Lomazzo's portrait and transformed them. For example, the golden water pitcher becomes the wedge of lemon, the grape vine is a tooth pick, and the olive branch becomes an acorn with foliage. These seductive innuendoes not only form the testa composta but also allude to a sexual grillo. Since Antiquity, the acorn, because of its shape and etymological association, was a reference to the male organ (Rackham, 1952, as cited in Duffin, Moody, \& Gardner-Thorpe, 2013; Lang et al., 1914; Wayne, 2017). ${ }^{17}$ Is Arcimboldo visually commenting on Lomazzo's art theory on grotteschi (considering Lomazzo's painting to be a reflection of grotteschi and a product of his academic endeavors on the art of allusions and metaphors)?

Perhaps in the depiction of metal plates and their reversible format into a helmet or protective hat, Arcimboldo alluded to another level of conceit: the military helmet used in battle as well as in joust celebrations. At this other symbolic level, was Arcimboldo referring to the futility of war like those battles endured for so long by the Milanese and Hapsburg reigns? He had designed helmets for the Hapsburg military court and was also familiar with the creation of war helmets during the 16th-century, not only in Germany but also in Milan at the court of Ludovico il Moro, where Leonardo designed them (Bambach, 2003).

In the other reversible painting, The Vegetable Gardener or The Bowls of Vegetables another type of signification is revealed (see Figure 5). One view is the collection of rich vegetables in a bowl: onions, carrots, mushrooms, squash, spinach, turnips, and various types of verdant vegetables. All flourishing vegetation produced during the season of autumn. The reversed view is an allegorical portrait of a laughing gardener, although there are aspects of previous depictions of the personification of autumn in his Four Seasons cycle (Cheney, 2008/2013/2015; Ferino-Pagden, 2007). The Vegetable Gardener is a unique conception of testa composta with vegetables. Some scholars view this picture as a reference to Priapus, the Greek protector of Livestock (fruit, plants, and vegetables), or to the God of Fertility because of the phallic allusion in the arrangement and the shapes of vegetables in the composition. A well-known image of Priapus as a God of Fertility was Francesco Colonna's Priapus in the Hypnerotomachia Poliphili (Aldine Press, Venice, 1499). ${ }^{18}$

Sixteenth-century emblematists, humanists, and poets, such as Pietro Aretino and Paolo Giovio wrote about ancient Rome's interest in engraving obscene images as tête composte (composite heads) on coins, medals, and plates as visualized in a drawing attributed to Leonardo, then used for an Italian medal or medals for Pietro Aretino or Paolo Giovio. The Medal of Aretino of 1530-1550 with a portrait head is inscribed on the recto "All in Every Part", while the verso bears a portrait as a phallus-head. ${ }^{19}$ A similar image is also represented in an Italian bowl, The Phallus Head of 1536, attributed to Francesco Urbini, at the Ashmolean Museum, which contains a long scroll with the inscription, "Every man looks at me as if I were a dickhead" (Ferino-Pagden, 2007). ${ }^{20}$ On the verso of the plate another inscription instructs the viewer to read the Latin inscription "from right to left", as when reading in Hebrew (see Figure 11). In a subtle manner, Arcimboldo also engaged in a sexual grillo in The Vegetable Gardener to entertain the viewer.

\footnotetext{
${ }^{17}$ In German or Dutch, the medical term eichel or eikel refers to the head of a penis, the so-called glans penis or acorn. See Hugo Lang et al., 1914), p. 107. In literature, see Wayne, 2017), p. 228, line 16 “full-acorned," a traditional reference to the glans penis or acorn.

18 For the image, see http://bdh-rd.bne.es/viewer.vm? id=24346\&page=203 (accessed April 24, 2018).

19 See Ferino-Pagden, Arcimboldo-Paris, p. 61; and for the image of the medal, see https://www.wga.hu/html_m/m/master/xunk_it/xunk_it7/10medal1.html (accessed April 24, 2018).

20 Another attribution for the plate is Maestro Giorgio Andreoli of the Gubbio Workshop. The plate contains an inscription in reverse on the banderole: ogni homo me guarda come fosse una testa de cazi (Every man looks at me as if I were a dickhead); on back: 1536/el breve dentro voi legerite come i guidei se intender el vorite (If you want to understand the meaning, you will be able to read the text like in Hebrew); also inscribed with painter's mark FR and a pair of scales.
} 


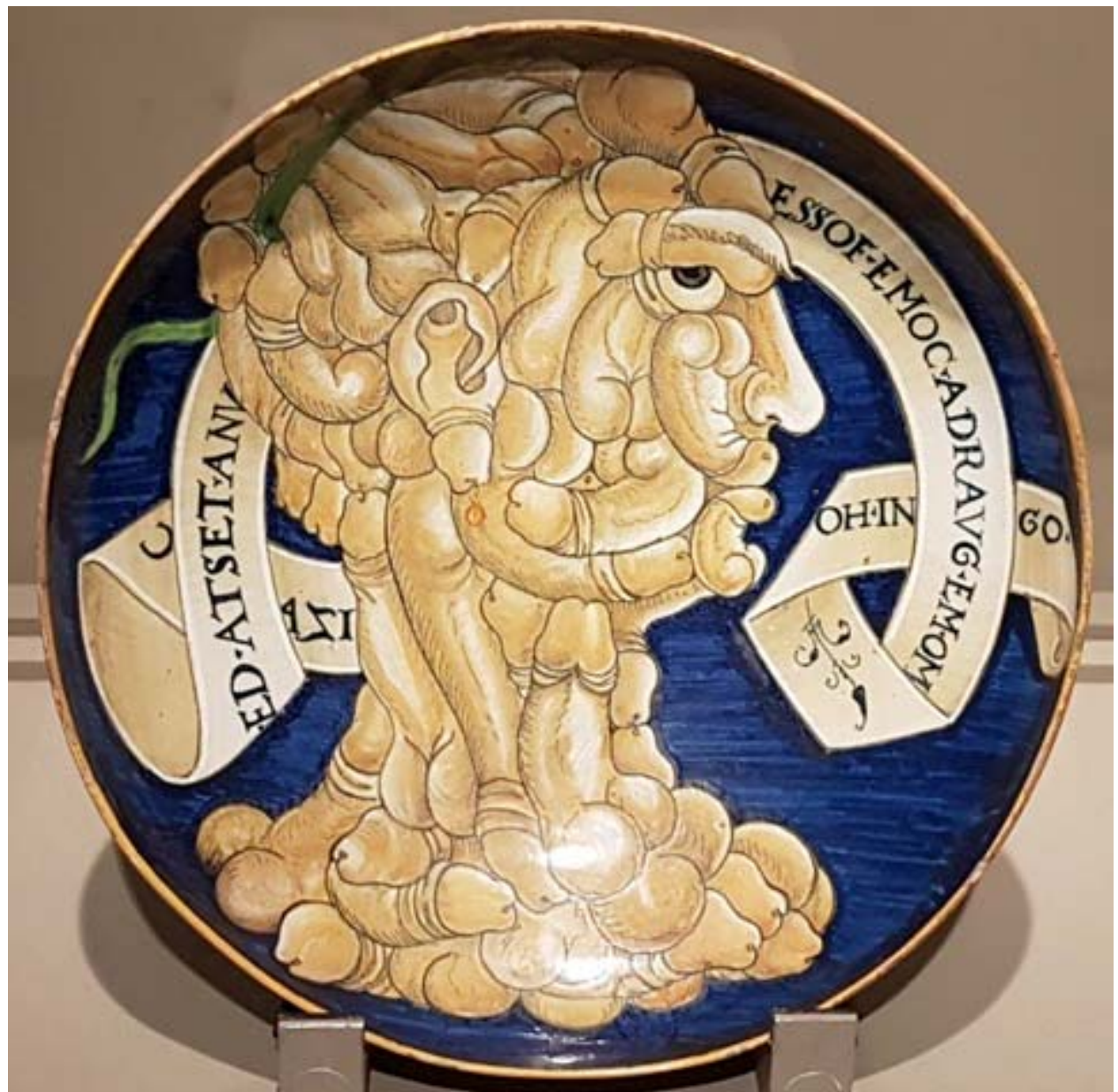

Figure 11. Francesco Urbini, Phallus Head, 1536. Maiolica plate. Ashmolean Museum, University of Oxford (Inv. WA1863.3907).

In The Basket of Fruits, reversed as Il Frutaio, The Fruit Vendor, of 1591 (see Figure 6), Arcimboldo returned to theme of the Seasons, in particular, his depiction of Summer as seen in the Louvre version of 1573, a work signed and dated in the figure's straw vest (Cheney, 2008/2013/2015; Ferino-Pagden, 2007). In The Fruit Vendor, the focus is on the richness and fecundity of the seasons of spring and summer. Arcimboldo visualized this earthly fruitfulness in creating a frontal portrait with copious and luscious depictions of fruits, flowers, and vegetables. Always using his grilli conceits, aesthetic elegance, and flair, the portrait depicts an elaborate and colorful harvest of the season. But in the reversal, a common basket forms the cap of the Frutaio. The large fruits, such as red apples and white stems of grapes form a jolly and tubby face. The laughing expression is forced, and the eyes are difficult to see. One seems to be squinting at the viewer, an invitation to indulge in the earthly fruits. The artificial portrait suggests a cheerful and mischievous contadino (peasant). Arcimboldo places the viewer in a quandary. Does the image or the contadino hide something from the viewer?

Arcimboldo's teste composte allude to the richness of earth, the fertility of flora and fauna, but most of all to the fertility of human creativity and the artistic ability to visualize it in order to evoke delight and laughter. The playful actions and fanciful depiction provoke in the viewer a humorous response, a sense of delight, a Neoplatonic “gracious laughter” (O’Rourke Boyle, 1999, pp. 712-741; Cast, 2009, Introduction). 


\section{Conclusion}

Under royal patronage as court painter and festival organizer for the Hapsburg family, Arcimboldo fused his artistic training and skills in cartoon designs for tapestries and stained-glass windows, as well as in fresco paintings with the portrayal of personifications of nature or of allegorical portraits (Kaufmann, 1988). ${ }^{21}$ The inventive and magnificent decoration and ornamentation in these allegorical and emblematic personifications of nature, elements, and individuals reveal his assimilation of classical whimsicality and Renaissance capricci, interjected with Arcimboldo's own intellectual playfulness. This latter interpretation fits with the style of Mannerism and its affinity, which is to compose imagery with, at once, complex and ambiguous symbolism for the intelligentsia, humanists, and artists.

Moreover, Arcimboldo's position at court was not just as a painter but also was as an inventor of musical arrangements, games, tournaments, spectacles, and costume designs for parades and various celebrations. Arcimboldo paralleled his activities to those of Leonardo's for the Duke of Milan and Giorgio Vasari's impresario ability for the Duke of Florence (Kaufmann, 1976). ${ }^{22}$ With Mannerist mastery Arcimboldo fused poetical metaphors into allegorical virtues without relinquishing the careful observation of the natural form. Since his grilli and teste composte reveal associations with the personification of the seasons and the elements, their imagery retains their originality and panache, as we still ponder on their signification.

Although partially forgotten from the 17th-century until the late 19th-century, Arcimboldo's artistic legacy was reinterpreted by the Symbolist painters, such as Odilon Redon and Arnold Böcklin, Surrealist artists, such as Salvador Dali, Marchel Duchamp, Max Ernest, and Rene Magritte, and today by contemporary painters such as Julie Heffernan (Hocke, 1977; Coen, 1987). ${ }^{23}$ Thus, Arcimboldo's grilli and teste composte imagery continues to harvest the imagination of the spectator, probing on the possibility of artistic creativity and the discovery of magic.

\section{References}

Acciarino, D. (2018). Lettere sulle grottesche (1580-1581) (Letters about grotesques). Canterano: Collana di Storia Dell’Arte Moderna.

Baltrasaïtus, J. (1987). Prima dell'Arcimboldi: Mostri e bizzarrie medievali (Before the Arciboldi: Medieval monsters and bizarre forms). In Arcimboldi e l'arte delle meraviglie (Arcimboldo and the art of wonders) (pp. 7-22). Florence: Giunti, Art Dossier.

Baltrusaïtis, J. (1987). Arcimboldo: A rose is a nose is a rose. Franco Maria Ricci, 24(January/February), 25-62.

Bambach, C. C. (Ed.). (2003). Leonardo da vinci master draftsman. New York: Metropolitan Museum Catalogue.

Benno Geiger, B. (1954). I dipinti ghiribizosi di Giuseppe Arcimboldi (Giuseppe Arcimboldi's capricious paintings). Florence: Vallecchi.

Berra, G. (1998). Arcimboldo, le “teste caricate” leonardesche e le "grillerie” dell’Accademia della Val di Blenio (Arcimboldi, Leonardesque “charged heads” and whimsicalities). In M. Kahn-Rossi \& F. Porzio (Eds.), Rabisch. Il grottesco nell'arte del Cinquecento. L'Accademia della Val di Blenio, Lomazzo e l'ambiente milanese, catalogo della mostra (Rabisch. The grotesque in the art of the sixteenth century. The Academy of Val di Blenio, Lomazzo and the Milanese culture, exhibition catalogue) (pp. 57-68). Milan: Skira.

\footnotetext{
${ }^{21}$ On his arrival in Vienna in 1563, under the patronage of Ferdinand I, king of Bohemia and then Hapsburg emperor, Arcimboldo painted the first cycle of the Four Seasons. The Austrian archival entries offer a luminous understanding of Arcimboldo's commissions during his tenure at the Hapsburg Imperial Court under Ferdinand I (1503-1564; r. 1558-1564), Maximilian II (1527-1576; r. 1564-1576), and Rudolph II (1552-1612; r. 1576-1612).

22 As a court painter and festival decorator, Arcimboldo revealed his concern for honoring the royal court that sponsored him. See Lomazzo, Idea del tempio della pittura, p. 154.

${ }^{23}$ See Hocke (1989), for one of the first essays on the influence of Arcimboldo's Mannerist style on the Surrealist artists.
} 
Bora, G., Kahn-Rossi, M., \& Porzio, F. (Eds.). (1988). Rabisch. Il grottesco nell'arte del Cinquecento. L'Accademia della Val di Blenio, Lomazzo e l'ambiente Mila nese (Rabisch. The grotesque in the art of the sixteenth-century. The academy of Val di Blenio, Lomazzo and the Milanese culture. Exhibition catalogue). Milan: Skira.

Calvesi, M. (1987). The Fonti dell’ Arcimboldi e il verde sogno di Polifilo (Arcimboldi’s sources and Poliphilo’s green dream). In J. Baltrusaïtis (Ed.), Arcimboldi e l'arte delle meravigle (Arcimboldo and the art of wonders) (pp. 28-52). Florence: Giunti.

Cast, C. (2009). The delight of art: Giorgio vasari and the traditions of humanist discourse. Philadelphia: Penn State University Press.

Castagno, P. C. (1994). The early commedia dell'arte (1550-1621): The mannerist context. Bern/New York: Peter Lang Publishing.

Chastel, A. (2010). La grottesca (The grotesque). (S. Lega, Trans.). Milan: Abscondita.

Cheney, L. D. G. (2008/2013/2015). Giuseppe Arcimboldo: Magical paintings. Paris: Parkstone Press International.

Cheney, L. D. G. (2017). Giorgio Vasari’s fine arts in the vite of 1550. Journal of Literature and Art Studies, 7(2), 140-178.

Chevalier, J., \& Gheerbrant, A. (1994). Dictionary of symbols. London: Blackwell.

Clayton, M. (2002). Leonardo da vinci: The divine and the grotesque. London: Royal Collection Enterprises.

Coen, E. (1987). Dopo l'Arcimboldi: Metamorfosi della psyche nell'arte moderna (After Arcimboldi: The metamorphosis of the psyche in modern art). In Arcimboldi e l'arte delle meraviglie (Arcimboldo and the art of wonders) (pp. 52-63). Florence: Giunti.

Comanini, G. (1591). Il Figino, overo, del fine della pittura: Dialogo (The Figino: About the nature of painting: Dialogue). Mantua: Osanna.

Doyle-Anderson, A., \& Maiorino, G. (Trans. and Eds.). (2001). Gregorio comanini, The Figino or on the purpose of painting: Art theory in the late Renaissance. Toronto: University of Toronto Press.

Duffin, C. J., Moody, R. T. J., \& Gardner-Thorpe, C. (2013). A history of geology and medicine. Exeter, UK: University of Exeter Medical School.

Ferino-Pagden, S. (Ed.). (2007). Arcimboldo. Paris: Musée du Luxemburg.

Ferino-Pagden, S. (Ed.). (2018). Il fascino bizzarro delle opera dell'Arcimboldo (The fascination for the bizarre in Arcimbolodi's works). Rome: Galleria Nazionale D’arte Antica.

Harpham, G. (1976). The grotesque: First principles. The Journal of Aesthetics and Art Criticism, 34(4), 461-468.

Hocke, G. R. (1977). Il mondo come labirinto (The world as a labyrinth). Rome: Theoria.

Impey, O., \& MacGregor, A. (Eds.). (2018). The origin of museums: The cabinet of curiosities in sixteenth-and seventeenth-century Europe. Oxford: Ashmolean Museum.

Isella, D. (Ed.). (1993). G. P. Lomazzo. Rabisch (G. P. Lomazzo’s Grotesques). Turin: Einaudi.

Kaufmann, T. D. (1976). Arcimboldo's imperial allegories: G. B. Fonteo and the interpretation of Arcimboldo's paintings. Zeitscrift für Kunstgeschichte, 39, 176-96.

Kaufmann, T. D. (2010). Arcimboldo: Visual jokes, natural history, and still-life painting. Chicago: University of Chicago Press.

Kaufmann. T. D. (1988). The School of Prague: Painting at the Court of Rudolph II. Chicago: The University of Chicago Press.

Kayser, W. J. (1981). The grotesque in art and literature. New York: Columbia University Press.

Kriegeskorte, W. (2004). Arcimboldo. Cologne: Taschen.

Kwakkelstein, M. (1994). Leonardo as a physiognomist: Theory and drawing practice. Leiden: Primavera Press.

Lang, H. et al. (1914). Lang's German-English dictionary of term used in medicine and the allied sciences. Philadelphia: Blakiston's Sons \& Co.

Lanzi, L. (1796). Storia pittorica della Italia (Pictorial history of Italy). Bassano: np.

Lomazzo, G. P. (1584). Trattato dell'arte della pittura, scultura et architettura (Treatise on the art of painting, sculpture and architecture). Milan: Ponto.

Lynch, J. B. (1964). Giovanni Paolo Lomazzo’s self-portrait in the Brera. Gazette des Beaux Arts, 64, 189-197.

Lynch, J. B. (1966). Lomazzo and the accademia della valle de bregno. Art Bulletin, 48, 210-211.

Maresca, P. (2012). Alchimia, magia e astrologia nella Firenze dei Medici: Giardini e dimore simboliche (Alchemy, magic and astrology in the Medicean Florence: symbolic gardens and homes). Florence: Angelo Pontecorboli.

Mauriès, P. (2011). Cabinet of curiosities. London: Thames and Hudson.

Morigia, M. (1595). Della nobilità di Milan (On the Milanese nobility). Milan: Da Ponte.

Morigia, P. (1592). Historia dell'antichità di Milano (History of ancient Milan). Venice: Guerra.

O’Rourke Boyle, M. (1999). Gracious laughter: Marsilio Ficino’s anthropology. Renaissance Quarterly, 52(3), 712-741. 
Orlandi, P. A. (1704). Abecedario pittorico. Bologna: Pisarri.

Praz, M. (1941/1947/1964). Studies in seventeenth-century imagery. London/Rome: Phaidon.

Rackham, H. (Trans. and Ed.). (1952). Natural History. Cambridge: London.

Ripa, C. (1603). Iconologia. Rome: Lepide Faeji.

Russell, D. (1981). Alciati’s Emblems in Renaissance France. Renaissance Quarterly, 34, 540-549.

Savio, F. (1905). Giovanni Battista Fontana or Fonteio scrittore milanese del sec. xvi (Giovanni Battista Fontana or Fonteio Milanese writer of the sixteenth-century). Archivio Storico Lombardo, 4(32), 343-375.

Seznec, J. (1953). The survival of the pagan gods. Princeton: Princeton University Press.

Tramelli, B. (2007). Giovanni Paolo Lomazzo's trattato dell'arte della pittura: Color, perspective and anatomy. Leiden: Brill. Vocabolario degli Accademici della Crusca. (1729). Florence: Manni.

Wayne, V. (Ed.). (2017). Shakespeare’s Cymbeline. London: Bloomsbury Arden Shakespeare.

Zamperinni, A. (2008). Ornament and the grotesque: Fantastical decorations from antiquity to art nouveau. London: Thames and Hudson.

Zeri, F. (1998/2001). Arcimboldo. Milan: RCS Libri. 